\title{
Pedagogical Course Projects: an interpretation through THE KNOWLEDGE MATRIX
}

\author{
PROJETOS PEDAGÓGICOS DE CURSOS: UMA INTERPRETAÇÃO POR MEIO DA MATRIZ DO \\ SABER
}

PROYECTOS PEDAGÓGICOS DEL CURSO: UNA INTERPRETACIÓN A TRAVÉS DE LA MATRIZ DEL SABER

\section{Ana Rita Levandovski \\ iD 9 \\ Doutora em Ensino de Ciências e \\ Educação Matemática (UEL) \\ Professora da Universidade Estadual \\ do Norte do Paraná (UENP) \\ anarita@uenp.edu.br}

\section{Marinez Meneghello Passos (iD) 9}

Doutora em Educação para a Ciência (UNESP)

Professora da Universidade Estadual de Londrina (UEL) e da Universidade Estadual do Norte do Paraná (UENP) marinez@uenp.edu.br

\section{Roberta Negrão de Araújo (iD) 9}

Doutora em Ensino de Ciências e Educação Matemática (UEL)

Professora da Universidade Estadual do Norte do Paraná (UENP)

robertanegrao@uenp.edu.br

\section{Sergio de Mello Arruda (iD) 9 \\ Doutor em Educação (USP) \\ Docente Sênior da Universidade \\ Estadual de Londrina (UEL) \\ Docente do Programa de Pós- \\ Graduação em Ensino \\ (PPGEN/UENP) \\ sergioarruda@uel.br}

\begin{abstract}
This article analyzes three Pedagogical Course Projects (PCP) in the field of Biological Sciences through a research instrument called the Knowledge Matrix - M(K). The methodological procedures were based on Discursive Textual Analysis (DTA). The vertical and horizontal readings of the $\mathrm{M}(\mathrm{K})$ Matrix revealed, respectively, the following distributions of the analyzed excerpts: $77.2 \%$ were in column 3 (teaching) and $85.5 \%$ were allocated in the first line (epistemic). Data analysis also revealed an important gap: the absence of excerpts in column 2 of the $\mathrm{M}(\mathrm{K})$, dedicated to the determinations of knowledge in relation to teacher learning. This is a concerning result, as the PCPs do not mention or provide considerations for teachers about how to conduct their classes (methodological aspects), how to think about content perspectives (epistemic aspects), and ultimately, how to develop the conditions of teacher action.

Palavras-chave: Knowledge Matrix. Biological Sciences. Pedagogical Course Project. Teacher Knowledge. Curricular knowledge.
\end{abstract}

Recebido em: 7 de outubro de 2021.

Aprovado em: 14 de dezembro de 2021.

Como citar esse artigo (ABNT):

LEVANDOVSKI, Ana Rita et al. Pedagogical Course Projects: an interpretation through the Knowledge Matrix. Revista

Prática Docente, v. 6, n. 3, e099, 2021.

http://doi.org/10.23926/RPD.2021.v6.n3.e099.id1322 


\section{Resumo}

O presente artigo analisa três Projetos Pedagógicos de Curso (PPC) da área de Ciências Biológicas por meio de um instrumento de pesquisa denominado Matriz do Saber - M(S). Os procedimentos metodológicos se fundamentaram na Análise Textual Discursiva (ATD). As leituras vertical e horizontal da Matriz $\mathrm{M}(\mathrm{S})$ revelaram, respectivamente, as seguintes distribuições dos excertos analisados: $77,2 \%$ incidiram na coluna 3 (ensino) e $85,5 \%$ foram alocados na primeira linha (epistêmica). A análise dos dados também revelou uma importante lacuna: trata-se da ausência de excertos na coluna 2 da Matriz $\mathrm{M}(\mathrm{S})$, dedicada às determinações do saber em relação à aprendizagem docente. Este é um resultado preocupante, visto que os PPC não fazem qualquer menção ou aportam considerações para os docentes formadores sobre como conduzir suas aulas (aspectos metodológicos), como pensar em perspectivas dos conteúdos (aspectos epistêmicos), enfim, como desenvolver os condicionantes da ação docente.

Keywords: Matriz do Saber. Ciências Biológicas. Projeto Pedagógico de Curso. Saberes Docentes. Saber curricular.

\section{Resumen}

Este artículo analiza tres Proyectos Pedagógicos del Curso (PPC) en el área de Ciencias Biológicas a través de un instrumento de investigación denominado Matriz del Saber - M(S). Los procedimientos metodológicos se basaron en Análisis Textual Discursivo (ATD). Las lecturas vertical y horizontal de la Matriz M (S) revelaron, respectivamente, las siguientes distribuciones de los extractos analizados: 77,2\% estaban en la columna 3 (enseñanza) y $85,5 \%$ estaban asignados en la primera línea (epistémica). El análisis de datos también reveló una brecha importante: la ausencia de extractos en la columna 2 de la Matriz M(S), dedicada a las determinaciones del conocimiento en relación con el aprendizaje docente. Este es un resultado preocupante, ya que los PPC no mencionan ni brindan consideraciones a los docentes formadores sobre cómo conducir sus clases (aspectos metodológicos), cómo pensar las perspectivas de contenido (aspectos epistémicos), en definitiva, cómo desarrollar las condiciones de acción del maestro.

Palabras clave: Matriz del Saber. Ciencias Biológicas. Proyectos Pedagógicos del Curso. Saberes Docentes. Saber Curricular. 


\section{INTRODUCTION}

From the 1980s onwards, studies in the field of teacher education aimed to investigate the knowledge base for teaching. International scholars such as Shulman (1986, 2005); Tardif (2000); Nóvoa (2009) and Gauthier et al. (2013) can be highlighted, in addition to Pimenta (1997), in Brazil. They mobilized efforts to investigate and systematize teacher knowledge. Thus, recent research in this field addresses teacher knowledge, which is part of everyday school life, as well as other knowledge that constitutes it.

The aforementioned researchers assume that teacher knowledge is social, heterogeneous, plural and temporal, acquired throughout the subject's history. It is evident that the teacher is always undergoing training and their knowledge in the field of teaching precedes their academic education, as they begin even before entering the licentiate degree ${ }^{1}$, still in the school desk as a student. (TARDIF, 2002).

Thus, teacher knowledge implies actions directly related to the work of teachers that goes beyond the classroom. In this sense, it is constituted as knowledge conceived by other original knowledge, such as curricular knowledge.

Inspired by studying the learner's relationships with the "[...] school world and, more specifically, the relationships with knowledge, teaching and learning in the classroom" (ARRUDA; PASSOS, 2017, p. 99, our translation), as indicated by the aforementioned authors, we chose to investigate the curricular knowledge in undergraduate Biological Sciences courses and observe particularities regarding the possibility of professional performance of the undergraduates who, even though were qualified in a degree, have the right to exercise not just teaching, but technical activities of the biologist (BRASIL, 1979).

In this context, the following research question was chosen: How do the Pedagogical Course Projects (PCP) in Biological Sciences guide the pre-service teacher education, from the perspective of the Knowledge Matrix - $\mathrm{M}(\mathrm{K})$ ? In the search for an answer to this question, we are dedicated to characterizing the curriculum as ordering the structure of academic education and interpreting the Pedagogical Course Projects (PCP) in Biological Sciences, having the $\mathrm{M}(\mathrm{K})$ as a foundation, with regard to teacher knowledge, especially in terms of curricular knowledge.

\footnotetext{
${ }^{1}$ A licentiate degree is an academic degree of higher education lasting approximately three to five years. In Brazil, it as a degree that enables the professional to act in their respective area, but mainly enabling them to be a teacher in Kindergarten, Elementary School, High School and Technical Education school levels.
} 
Having posed the research question that we focus on in this article, we bring some clarifications about curriculum and PCP.

Regarding the concept of curriculum which, in the light of Sacristán (2013) is understood as an instrument responsible for aggregating and organizing the contents to be studied at a given level of academic instruction by those in the process of development, there is a need to broaden the reflection, without losing sight of its dynamic and transitory nature. Arroyo (2008), considering these characteristics, reaffirms that the issues related to the curriculum, present in educational institutions:

[...] and in pedagogical theory show a first meaning: the awareness that curricula are not content ready to be passed on to students. They are a construction and selection of knowledge and practices produced in concrete contexts and in social, political and cultural, intellectual and pedagogical dynamics. Knowledge and practices exposed to new dynamics and reinterpreted in each historical context. The inquiries reveal that there is an understanding that curricula are guided by the dynamics of society (ARROYO, 2008, p. 9, our translation).

The inquiries of educational institutions and professionals regarding the educational purposes of the curriculum require a reflective exercise that includes questions related to the social dynamics, culture and politics of that social context, having as a reflective basis the knowledge and educational practices of the institution in question (ARROYO, 2008).

Silva (2017) defends that the fundamental point for the constitution of any curriculum consists in knowing what knowledge needs to be taught and improved. That is, what to teach so as to develop the student. For this reason, curriculum theories are committed, in an evident or hidden way, "[...] to develop selection criteria that justify the answer they will give to that question. The curriculum is always the result of a selection: from a broader universe of knowledge, a part is selected that will constitute, precisely, the curriculum" (SILVA, 2017, p. 15 , our translation).

In this scenario, the articulating and indispensable role of the relationship between the curriculum and the Pedagogical Course Project (PCP) is established. This is because, based on the aforementioned authors, the curriculum is understood as part of a broader project, capable of translating the educational proposal of an educational institution and, in the case of this research, of undergraduate courses.

This document, of public domain, is an instrument that indicates the academic actions that guide the management and pedagogical activities of each undergraduate course in the university context. It is the identity of a course, as "[...] there is no isolated course project. It is part of an institutional project, which is part of a university, which is part of an education 
system, which is part of a society project" (VEIGA, 2004, p. 17, our translation). A document drawn up in a collective and participatory manner by members of the course, observing institutional guidelines and norms. According to Veiga (2004, p. 25, our translation):

The political-pedagogical project is more than an established formality: it is a reflection on higher education, on teaching, research and extension, on the production and socialization of knowledge, on the student and the teacher and on the pedagogical practice that takes place at the university. The political-pedagogical project is a closer approximation between what is instituted and what becomes instituting. Thus, the articulation of the instituted with the instituting enables the expansion of knowledge.

In the sphere of national legislation, the greater emphasis on the elaboration of pedagogical projects is supported by the Law of Guidelines and Bases for National Education (LDBEN, Portuguese: Lei de Diretrizes e Bases da Educação Nacional), of n. 9394/96, of December 20, 1996, item I of Article 12, by stating that "Education establishments, respecting the common standards and those of their education system, will have the task of preparing and executing their pedagogical proposal" (BRASIL, 1996, our translation), whose autonomy is reinforced in item II of Article 53 of the same Law:

Art. 53. In exercising their autonomy, universities are assured, without prejudice to others, the following attributions:

$[\ldots]$

II - establish the curricula of its courses and programs, observing the relevant general guidelines (BRASIL, 1996, our translation).

As a result of the LDBEN, the National Curriculum Guidelines for Courses (DCN, Portuguese: Diretrizes Curriculares Nacionais dos Cursos) are reference documents for the organization and preparation of higher-level courses. Issued by the Higher Education Chamber (CES, Portuguese: Câmara de Educação Superior) of the National Education Council (CNE, Portuguese: Conselho Nacional de Educação), Ministry of Education (MEC, Portuguese: Ministério da Educação), the Guidelines are specific for each course.

In the case of the Biological Sciences course, the documents that guide the formulation of the pedagogical project are: the National Curriculum Guidelines for Biological Sciences Courses - Report of CNE/CES n ${ }^{\circ}$ 1.301/2001, of November 6, 2001 and Resolution CNE/ CES $\mathrm{n}^{\mathrm{o}}$ 2, of February 19, 2002-A; and CNE/CES Resolution n ${ }^{\circ}$ 7, of March 11, 2002-B.

However, it is up to educational institutions to define, plan, propose and, then, carry out actions that direct academic education for a particular purpose. In the characteristics of a project, this instrument presents teaching and learning concepts that reveal the educational and professional education intention of a given course, in this case, an undergraduate course. 
With regard to the composition of the investigated $\mathrm{PCP}$, internal references are found in the Statute and in the General Regulations of the Higher Education Institution (HEI), as well as in institutional regulations approved by Internal Councils, from which the effective work of elaboration and evaluation of proposals can be undertaken.

It should be noted that the aforementioned regulatory acts reinforce the competence and autonomy of the Course Collegiates in the elaboration of their pedagogical proposals, as it is understood that this is the competent body for the structuring of the course curriculum, in compliance with federal legislation. It is, therefore, up to subsequent and superior instances to verify compliance with legislation and the technical-administrative possibilities of implementing the projects proposed by the courses, so that, when reflecting on the organizational structure of undergraduate courses, it is essential to consider the constitution of the document that aims to present the course to the academic community as a pedagogical instrument.

A PCP is elaborated in conceptual groups, which are: foundation and guiding principles; curriculum organization and disciplinary programs; and, regulations. The definition of the curriculum and disciplinary programs is established based on assumptions and fundamentals, as well as the institution's teaching policies, and unfolds into the complementary regulations necessary for the full development of the curricular proposal.

Araújo, when discussing the formation of teacher identity, indicates that

[...] the individual builds their identity in the interaction with another. This construction is related to the context in which the subject is inserted, which allows (or not) their experiences, reaching the necessary attributes. Our identity is our way of seeing, feeling, thinking and acting about the world based on the relationships established with our peers in the environment in which we live (ARAÚJO, 2017, p. 20 , our translation).

Therefore, the knowledge that constitutes the curriculum and, in this case also the PCP, are strongly related to training and professional identity, since "[...] the teacher identity results from the effect of relationships with teachers (and their teacher knowledge), with educational institutions" (ARAÚJO, 2017, p. 58, our translation) with the pedagogical team, with the students and with their own knowledge.

It is in this context of inseparability between curriculum, PCP and teacher education that this research, whose results we present in this article, was developed. The undergraduate courses in Biological Sciences investigated were coded with the letter C, followed by a numeral determined from the alphabetical order corresponding to the name of the Institution $(\mathrm{C} 1, \mathrm{C} 2$ 
and C3). These courses are structured in different ways and each one has its own specificities. During the period in which the research was developed, of the three courses, two were offered in the licentiate degree and one was offered as a dual modality: licentiate and bachelor's degree. In view of this, seeking information on the three made it possible to perceive pedagogical and curricular characteristics of each course.

It should also be noted that the $\mathrm{M}(\mathrm{K})$ has already been applied in other investigative situations: in one of them, with the purpose of analyzing the curriculum change process of a Federal Institute of Paraná (IFPR, Portuguese: Instituto Federal do Paraná) where the research data were minutes of a meeting of the curriculum committee (CORRÊA; ARRUDA; PASSOS, $2020)$; in the other, the $M(K)$ was used to validate the applicability of a didactic guide produced for the Teaching of Chemistry. In this case, the corpus ${ }^{2}$ interpreted and allocated in the Matrix was constituted of the accounts of Biological Science students from a State University of Paraná, regarding the chemical contents present in the guide (RISSI, 2020).

Next, we bring: information about the theoretical foundation used during the development of the research; clarification on methodological procedures, data collection and organization; several details about the results found; the final considerations that this analytical process provided. It should be noted in this introduction that the entirety of the research can be accessed in Levandovski (2019).

\section{THEORETICAL FOUNDATION}

This section is divided into three parts: the first deals with teacher knowledge, focusing mainly on Shulman and Tardif; in the second, we talk about the relationship with knowledge in the classroom; finally, in the last part of the section, we present the Knowledge Matrix, $M(K)$, as the main instrument for analyzing the data investigated here.

\subsection{TEACHER KNOWLEDGE}

In the 1980s, the researcher Shulman defended that the advancement of knowledge in the educational field would need to have the development and education of teachers as a proposal. In this sense, the author stated that such studies needed to investigate where teachers' explanations in the act of teaching come from. This defense was an important milestone for the time, considering that studies on teaching in that period tended to ignore issues related to the

\footnotetext{
2 "[...] the set of documents taken into account to be submitted to the analytical procedures" (BARDIN, 2011, p. 126 , our translation).
} 
teacher and concentrated efforts on themes related to learning, with an emphasis on cognitive psychology (SHULMAN, 1986; MARTINEAU; GAUTHIER, 1999; GAUTHIER et al., 2013).

Thus, there was a need for studies that sought a balance between the pedagogical aspect and the scientific knowledge necessary for the practice of teaching. For Shulman $(1986,2005)$, research on teacher knowledge needed to be based on characteristics such as knowledge, understanding, skills and the disposition necessary for the teacher's efficient performance in teaching. And among Shulman's areas of investigation, the education the Biology teacher received was contemplated (the focus of the research carried out by us).

Shulman (1986) and his collaborators then began to consider as a central point of study the transition of the university student from the teaching field to that of the teacher at the beginning of their career. Among the investigative concerns, they sought to know how university students transformed academic knowledge into school knowledge to be transmitted and learned by students. Shulman specified three types of teacher knowledge (SHULMAN, 1986, p. 9): subject matter knowledge, pedagogical content knowledge and curricular knowledge.

Shulman was known, mainly, for the proposition that, in addition to knowledge of the subject to be taught, there would be a pedagogical content knowledge, defined by him as follows:

\footnotetext{
A second kind of content knowledge is pedagogical knowledge, which goes beyond knowledge of subject matter per se to the dimension of subject matter knowledge for teaching $[\ldots]$ Within the category of pedagogical content knowledge I include $[\ldots]$ the ways of representing and formulating the subject that make it comprehensible to others (SHULMAN, 1986, p. 9).
}

Likewise, different studies in the field of teacher education from that period considered that, although the teacher's knowledge of the content was repeatedly "[...] found to be an important factor in teaching effectiveness, it appears that its relationship to teaching performance is curvilinear; that is, it exerts a positive effect up to a threshold level and then tapers off in influence" (DARLING-HAMMOND, 2015, p. 233, our translation). According to the author, the teacher's pedagogical domain, which includes knowledge about learning, how to learn, as well as the proper use of teaching methodologies and curriculum knowledge, bring more effective results for student instruction.

Here, we will adopt Tardif's definition of what teacher knowledge would be: "Teacher knowledge can be defined as a plural knowledge, formed by the more or less coherent 
amalgamation of knowledge derived from professional education and disciplinary, curricular and experiential knowledge" (TARDIF, 2002, p. 36, our translation).

In this article, we are particularly interested in curricular knowledge, understood as:

[...] discourses, objectives, contents and methods from which the school institution categorizes and presents the social knowledge defined and selected by it as models of high culture and education for high culture. They are concretely presented in the form of school programs (goals, contents, methods) that teachers must learn to apply (TARDIF, 2002, p. 38, our translation).

\subsection{THE RELATIONSHIP WITH KNOWLEDGE IN THE CLASSROOM}

For about ten years we have been dealing with the dynamics of teaching and learning processes in the classroom, creating research instruments (ARRUDA; LIMA; PASSOS, 2011; ARRUDA; PASSOS, 2017), reflecting on the relationships with knowledge in the classroom (ARRUDA; PASSOS, 2015) and about the actions of teachers, students and their connections (ARRUDA; PASSOS; BROIETTI, 2021). In all of the research, we have adopted as a basis a standard classroom model called the didactic-pedagogical triangle, represented in Figure 1:

Figure 1 - Didactic-pedagogical triangle

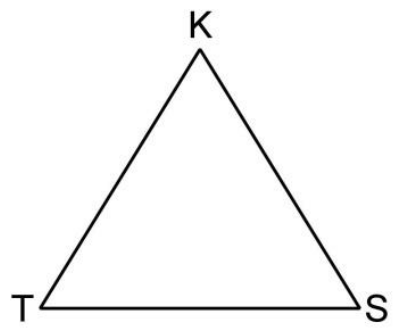

Source: Adapted from Arruda and Passos (2015).

In Figure 1, $\mathrm{S}$ is the student or a class, $\mathrm{T}$ is the teacher and $\mathrm{K}$ is the knowledge to be taught, which establish different relationships with teaching, learning and knowledge. In this figure, the segments are understood as follows:

S-T (or T-S) indicates the relationships between the teacher and the students and represents teaching. S-K (or K-S) indicates the relationships between students and knowledge and represents student learning. T-K (or K-T) indicates the relationship between teacher and knowledge and represents teacher learning (ARRUDA; PASSOS, 2017, p. 100, our translation).

Having as theoretical support writings by Bernard Charlot, we assume with this author that the relationship with knowledge is, in general, "a form of relationship with the world" (CHARLOT, 2000, p. 78, our translation), where the world can be understood as a set of meanings, which precede the person's birth and also as a space for carrying out activities. 
We are particularly interested in the relationship with knowledge in the classroom, the space represented by Figure 1, where knowledge (K) circulates, establishing relationships with actors T and S. In usual situations, knowledge is the school content (the subject to be taught or a specific content), but it can be understood, in a broader way, as teacher knowledge, as defined by Tardif (knowledge of professional, disciplinary, curricular and experiential education).

Another assumed assumption, also originating from the reading of Charlot, is what we call R3 relations, that is, the epistemic, personal and social relations with knowledge in the classroom, defined in Table 1:

Table 1 - Epistemic, personal and social relationships with the school world (R3)

a) Epistemic relationship: the subject demonstrates an epistemic relationship with the school world when they use purely intellectual or cognitive discourses about teaching, learning and the events that occur in this universe, expressing themselves, in general, through oppositions such as I know/I don't know, I understand/I don't understand, etc.

b) Personal relationship: the subject demonstrates a personal relationship with the school world when they use discourses that refer to feelings, emotions, senses, desires and interests, expressing themselves, in general, through oppositions such as I like/I dislike, I want/I don't want, I feel/I don't feel etc.

c) Social relationship: finally, the subject demonstrates a social relationship with the school world when they use discourses that involve values, agreements, precepts, beliefs, laws, which originate inside or outside the school world, expressing themselves, in general, through oppositions of the type I value/I don't value, I should/I shouldn't (do), I can/I can't (I am or am not authorized to do) etc.

Source: Adapted from Arruda and Passos (2017).

Based on the ideas briefly exposed, it was possible to demonstrate that the application of the R3 relations (Table 1) to the didactic-pedagogical triangle (Figure 1) generates three research instruments called the: Teacher Matrix, M(T); Student Matrix, M(S); and Knowledge Matrix, $\mathrm{M}(\mathrm{K})^{3}$. In the next subsection we describe the $\mathrm{M}(\mathrm{K})$ Matrix in more detail.

\subsection{THE KNOWLEDGE MATRIX - M(K)}

The PCPs were analyzed based on the research instrument referred to in the previous section as the Knowledge Matrix, abbreviated as $\mathrm{M}(\mathrm{K})$ and described in Arruda and Passos (2017). This Matrix "[...] addresses the effects of the (indirect) action of knowledge in the classroom, focusing on documents, objects and activities that somehow influence its functioning" (ARRUDA; PASSOS, 2017, p. 103, our translation). The M(K) Matrix, described in Table 2, is a very suitable instrument to analyze the effects of curricular action on the relationships, perceptions and actions of teachers and students in the classroom.

\footnotetext{
${ }^{3}$ The procedures for creating these research instruments are described at length in Arruda and Passos (2017), so we will not detail this point in this article.
} 
Table 2 - Knowledge Matrix M(K)

\begin{tabular}{|c|c|c|c|}
\hline $\begin{array}{l}\text { Reterminations of } \\
\text { knowledge } \\
\text { Relationships } \\
\text { with knowledge }\end{array}$ & $\begin{array}{c}1 \\
\text { About student learning } \\
(\mathrm{K}-\mathrm{S} \text { segment })\end{array}$ & $\begin{array}{c}2 \\
\text { About teacher learning } \\
\text { (K-T segment) }\end{array}$ & $\begin{array}{c}3 \\
\text { About teaching } \\
\text { (Segment T-S) }\end{array}$ \\
\hline $\begin{array}{c}\alpha \\
\text { Epistemic } \\
\text { (knowledge) }\end{array}$ & $\begin{array}{l}\text { 1 } \alpha \text { cell } \\
\text { It concerns the } \\
\text { determinations of } \\
\text { knowledge in relation to } \\
\text { student learning from an } \\
\text { epistemic point of view }\end{array}$ & $\begin{array}{c}2 \alpha \text { cell } \\
\text { It concerns the } \\
\text { determinations of knowledge } \\
\text { in relation to teacher } \\
\text { learning from an epistemic } \\
\text { point of view }\end{array}$ & $\begin{array}{c}3 \alpha \text { cell } \\
\text { It concerns the } \\
\text { determinations of } \\
\text { knowledge in relation to } \\
\text { teaching from an epistemic } \\
\text { point of view }\end{array}$ \\
\hline $\begin{array}{c}\boldsymbol{\beta} \\
\text { Personal } \\
\text { (sense) }\end{array}$ & $\begin{array}{c}1 \beta \text { cell } \\
\text { It concerns the } \\
\text { determinations of } \\
\text { knowledge in relation to } \\
\text { student learning from a } \\
\text { personal point of view }\end{array}$ & $\begin{array}{c}2 \beta \text { cell } \\
\text { It concerns the } \\
\text { determinations of knowledge } \\
\text { in relation to teacher } \\
\text { learning from a personal } \\
\text { point of view }\end{array}$ & $\begin{array}{c}3 \beta \text { cell } \\
\text { It concerns the } \\
\text { determinations of } \\
\text { knowledge in relation to } \\
\text { teaching from a personal } \\
\text { point of view. }\end{array}$ \\
\hline $\begin{array}{c}\gamma \\
\text { Social } \\
\text { (value) }\end{array}$ & $\begin{array}{c}1 \gamma \text { cell } \\
\text { It concerns the } \\
\text { determinations of } \\
\text { knowledge in relation to } \\
\text { student learning from a } \\
\text { social point of view }\end{array}$ & $\begin{array}{c}2 \gamma \text { cell } \\
\text { It concerns the } \\
\text { determinations of knowledge } \\
\text { in relation to teacher } \\
\text { learning from a social point } \\
\text { of view. }\end{array}$ & $\begin{array}{c}3 \gamma \text { cell } \\
\text { It concerns the } \\
\text { determinations of } \\
\text { knowledge in relation to } \\
\text { teaching from a social } \\
\text { point of view }\end{array}$ \\
\hline
\end{tabular}

Source: Arruda and Passos (2017, p. 111-112, our translation).

Next, we detail the characterization of the nine cells of the Knowledge Matrix (considering them line by line), based on Arruda, Lima and Passos (2011), Arruda, Benicio and Passos (2017) and Arruda and Passos (2017).

Sector $1 \alpha$ concerns the determinations of knowledge (Biology PCP) about the learning of Biological Sciences students; to the ways in which they appropriate knowledge, how they seek to understand it more and more. It is about the influence of the PCP in the learning process of these students. Sector $2 \alpha$ concerns the determinations of knowledge (Biology PCP) about the learning of teachers who form the Biological Sciences course; to the ways in which they appropriate knowledge, how they seek to understand. It deals with the influence of PCP in the teacher's learning process as a trainer of new biologists. Sector $3 \alpha$ concerns the determinations of knowledge (Biology PCP) about teaching in the Biological Sciences course, from the systematization of the pedagogical process, as in the case of syllabus, to the assessment procedures, methodological procedures and other curricular components related to the epistemic dimension.

Sector $1 \beta$ concerns the determinations of knowledge (Biology PCP) in relation to the learning of Biological Sciences students in the personal sphere. How much the student is involved with the course, with the curricular components offered; how much is he/she building a professional identity for being in that academic context. Sector $2 \beta$ concerns the determinations 
of knowledge (Biology PCP) in relation to the learning of the Biological Sciences course teacher in the personal sphere. How much the professor is involved with the course, with the curricular components, how much of a personal sense is given to the profession, to the proper way of applying and practicing the rules and guidelines of the PCP for the education of the students. The $3 \beta$ sector concerns the determinations of knowledge (Biology PCP) about teaching, in the Biological Sciences course, in the personal dimension. The meaning that teaching acquires in the course, how much does it imply in involvement, motivation and interest in the interactions between teachers and students.

Sector $1 \gamma$ concerns the determinations of knowledge (Biology PCP) on the learning of undergraduate students in Biological Sciences from a social point of view. The profile of the professional expected to be trained, their ethical-professional commitments, their skills and qualifications for exercising the profession in society. Sector $2 \gamma$ concerns the determinations of knowledge (Biology PCP) on the learning of the Biological Sciences course teacher in the social sphere. From the professional profile expected from teacher trainers, from their ethicalprofessional commitments, their abilities to interact with actors in the professional context and to negotiate values with a view to the education of their students. Sector $3 \gamma$ concerns the determinations of knowledge (Biology PCP) related to teaching from the social point of view. To teaching as a social and interactive activity, to the value of teaching for the formation of new biologists and the impact of this movement on society.

In order to clarify a little more about $\mathrm{M}(\mathrm{K})$ we indicate that $\mathrm{K}$ can be thought of as something that guides the functioning of the triangle (see Figure 1), as a non-human "actor" or actant in the sense given by Latour (2001, p. 246). As the element that:

[...] establishes the teaching and learning objectives to be achieved, which involve: (i) planning, which specifies contents and methods (the curriculum of a course, the political-pedagogical project, a PBL proposal, the program of a discipline, the planning of a lesson, a didactic sequence, etc.); (ii) virtual or physical teaching aids or materials (books, e-books, websites, equipment, learning objects, etc.); (iii) organized activities or processes (experiments, games, problem solving, scripts, etc.) (ARRUDA; PASSOS, 2017, p. 102, our translation).

Next, we go to the methodological procedures of this research.

\section{METHODOLOGICAL PROCEDURES}

In this section we bring the methodological procedures about the investigative proposal on the curricular knowledge in the teacher education of teachers in the investigated Biological Sciences courses. 
This is a qualitative research, an approach widely used in the Human Sciences as it favors the study of themes that are not strictly quantifiable, as in the case of issues related to the process of teacher education.

According to Bogdan and Biklen (1994), qualitative research has very specific characteristics, such as the collection of data rich in details, the clarification of the research context and other relevant factors that can capture the complexity of the investigated phenomena as much as possible. For the aforementioned authors, a researcher who develops this type of investigation aims to "[...] understand human behavior and experience. [...] understand the process through which people construct meanings and describe what these same meanings consist of" (BOGDAN; BIKLEN, 1994, p. 70, our translation).

In this investigative path, observation and data collection through records that can be transcribed favor the development of analyzes about human conditions in their contextual richness.

As indicated above, we dedicated ourselves to the study of three Biological Sciences Courses offered at public universities in Paraná, and whose analysis of their PCP provided an opportunity to take objective data, that is, their textual content. This step involved the use of the $\mathrm{M}(\mathrm{K})$ Matrix, described in the previous section, whose cells were considered as a priori categories.

Of the investigated courses, coded as $\mathrm{C} 1, \mathrm{C} 2$ and $\mathrm{C} 3$, two of them $(\mathrm{C} 1$ and $\mathrm{C} 2)$ were created in the 1970s. While C3, much more recent, was created in the late 1990s.

In the general organization of the PCP, the curricular components have their consequences in the form of mandatory, elective or optional subjects. In the configuration of mandatory components, these can be listed, in general as: the Mandatory Supervised Internship; the Term Paper (TP), the Complementary Academic Activities (CAA), the AcademicScientific-Cultural Activities (ASCA) and other activities that are presented in the respective PCP of each course, as well as the offer of elective and optional subjects.

In the case of electives, they are subjects related to the course area for the purpose of curricular integration, offered in other classes, shifts or courses that may be part of the academic education. Optional subjects, on the other hand, allow the academic to choose a certain subject, even if it is not related to the course they belong to. This possibility of expanding the curriculum autonomously by the academic, choosing to take non-mandatory subjects, is provided for in the three PCPs. 
When seeking identification data for each Biological Sciences course in the PCP, it was observed that they present specifics in how they are offered, as shown in Table 3.

Table 3 - Course identification data

\begin{tabular}{|c|c|c|c|c|c|}
\hline Course & Modality & Class time & Course hours & Duration & $\begin{array}{c}\text { Student } \\
\text { slots }\end{array}$ \\
\hline C1 & $\begin{array}{c}\text { Licentiate Degree in } \\
\text { Biology }\end{array}$ & Night & 3.730 & 5 years & 40 \\
\hline C2 & $\begin{array}{c}\text { Licentiate Degree in } \\
\text { Biology }\end{array}$ & Night & 3.100 & 4 years & 40 \\
\hline C3 & $\begin{array}{c}\text { Licentiate and Bachelor's } \\
\text { Degree in Biological } \\
\text { Sciences }\end{array}$ & Full time & 4.745 & 5 years & 50 \\
\hline
\end{tabular}

Source: Data obtained in the survey.

Given the above, it was observed that, despite the courses meet the same national and state legislation, each is structured differently, reflecting, therefore, on the pedagogical practice of the teacher trainer and the academic training of their undergraduates. Therefore, we believe that a detailed analysis of their Pedagogical Projects could favor the disclosure of underlying curricular knowledge, which became our research focus.

Thus, considering the PCP, it was observed that the documents have a very similar structure, as shown in Table 4, in which the Structuring Axes are presented in the first column and general information in the second column.

Table 4 - Structure of Pedagogical Course Projects

\begin{tabular}{|c|c|}
\hline $\begin{array}{c}\text { Axis I - Presentation/ } \\
\text { Foundation }\end{array}$ & General Data - Guiding Principles \\
\hline 1.1 Identification data & $\begin{array}{l}\text { 1.1.1 Course: (Modality/Qualification/Emphasis): } \\
\text { 1.1.2 Title (Degree) of: } \\
\text { 1.1.3 Total course hours: } \\
\text { 1.1.4 Duration: } \\
\text { 1.1.5 Time offered } \\
\text { 1.1.6 Working place: University Campus...... } \\
\text { 1.1.7 Regime - Annual Series } \\
\text { 1.1.8 Current number of student slots: } \\
\text { 1.1.9 Admission conditions: selection process; external transfer, holder of higher } \\
\text { education diploma. }\end{array}$ \\
\hline 1.2 Current legislation & $\begin{array}{l}\text { 1.2.1 Creation: } \\
\text { 1.2.2 Authorization: } \\
\text { 1.2.3 First Recognition: } \\
\text { 1.2.4 Last Renewal of Recognition }\end{array}$ \\
\hline 1.3 History and diagnosis & $\begin{array}{l}\text { 1.3.1 Survey of course data (clients served during operation, slots offered, } \\
\text { demand, dropouts, etc.) } \\
\text { 1.3.2 Curriculum changes occurred } \\
\text { 1.3.3 Class period changes } \\
\text { Description of the current status of the course in relation to the undergraduates } \\
\text { (quality of the course, professional profile) }\end{array}$ \\
\hline
\end{tabular}




\begin{tabular}{|c|c|}
\hline $\begin{array}{l}1.4 \text { Course Structure - } \\
\text { curriculum components }\end{array}$ & 1.4.1 Presentation of the Course Curriculum \\
\hline $\begin{array}{l}1.5 \text { Relation to extension, } \\
\text { research and graduate studies }\end{array}$ & $\begin{array}{l}\text { 1.5.1 Description of the current status of the course in relation to the students } \\
\text { who are graduating }\end{array}$ \\
\hline $\begin{array}{l}\text { 1.6 Faculty Acting on the } \\
\text { Course }\end{array}$ & $\begin{array}{l}\text { 1.6.1 Titles } \\
\text { 1.6.2 Work regime }\end{array}$ \\
\hline $\begin{array}{l}1.7 \text { Existing material } \\
\text { resources }\end{array}$ & 7.1 Describe the infrastructure (classrooms, electronic equipment, etc.) \\
\hline $\begin{array}{l}\text { Axis II - Curriculum } \\
\text { Organization }\end{array}$ & Course Curriculum and Syllabus \\
\hline 2.1 Objectives & 2.1.1 Course purpose \\
\hline 2.2 Professional Profile & $\begin{array}{l}\text { 2.2.1 Technical characteristics } \\
\text { 2.2.2 Skills Required }\end{array}$ \\
\hline 2.3 Assessment system & $\begin{array}{l}\text { 2.3.1 Mention how the assesment is in the regulations of the HEI and that it will } \\
\text { be adopted in the new project }\end{array}$ \\
\hline 2.4 Syllabuses & 2.4.1 Syllabuses of the subjects per academic period \\
\hline 2.5 Supervised internship & 2.5.1 Organization, workload and internal regulations \\
\hline Axis III - Regulations & Course Regulations for Specific Curriculum Components \\
\hline 3.1 Basic legislation & $\begin{array}{l}\text { 3.1.1 National and state curriculum guidelines (DCN), reports and resolutions } \\
\text { regarding the course } \\
\text { 3.1.2 Legislation that regulates the profession that the course enables to exercise } \\
\text { Mandatory Supervised Internship (regulations) } \\
\text { 3.1.3 Academic-Scientific-Cultural Activities - ASCA (regulations) } \\
\text { 3.1.4 Practice as a Curriculum Component - PCC (regulations) } \\
\text { 3.1.5 Course completion work or Term Paper - TP (regulations) }\end{array}$ \\
\hline
\end{tabular}

Source: Data obtained in the survey.

Axes I and III deal with technical information about the courses, such as their identification, legislation, composition, history, faculty and resources. The prescriptive elements do not provide data for an analysis aimed at the pedagogical education, being linked to the general characterization of the courses.

From this basic structure, it was considered pertinent, then, to analyze the Structuring Axis II (Curriculum Organization), since it deals with issues that characterize the pedagogical training of undergraduates and which are related to the curricular organization of the course, highlighted with shading in the previous table.

According to the proposal itself, the highlighted Curriculum Organization aims to systematize an undergraduate course that studies the relationship between living beings and the environment, as well as the processes and regulatory means of life. Thus, the teacher trained in the area needs to have knowledge of nature, understanding the evolutionary process over the course of human history and its interdependent relationships and species diversity. 
Understanding such relationships involves knowledge of the physical conditions of the environment, the way of life and the functional organization of species and biological systems. However, teacher education has as a priority to understand "[...] the relationships established by human beings, given their specificity. In such an approach, biological knowledge is not dissociated from social, political, economic and cultural knowledge" (BRASIL, 2001, p. 01, our translation).

The processing of information was possible through following the methodological guidelines: first, the sections that would be analyzed were selected, as many of them dealt with legislation and technical data of the courses, such as number of slots, period offered, method of payment, not configuring content of interest for this research. In this sense, sections dedicated to the curricular components of each course and how they are fulfilled were selected: Objectives, Professional Profile, Assessment System, Syllabus and Supervised Internship.

Then, so that the information contained in the analyzed sections of the PCP could be applied to the Knowledge Matrix, this entire textual body was submitted to the initial phases of Discursive Textual Analysis (DTA), as suggested by Moraes and Galiazzi (2011).

The deconstruction of the corpus texts and the unitarization - the two initial stages indicated by DTA - allowed us to arrive at textual excerpts from the PCP that were categorized in the cells of the Knowledge Matrix. For that, the established analysis procedure considered the following steps: a) selection of the PCP analysis sections of the three participating courses; b) repeated readings of the textual content of the selected sections of the $\mathrm{PCP}$, enabling the application of these steps already highlighted. Continuing, we advance to a third stage, the codification of the excerpts and their accommodation in the Knowledge Matrix. Finally, in the fourth process, we performed the interpretation of the Matrix generated for each PCP with the following analytical order: vertical reading of the distributions of the excerpts, starting with the columns, from the cells with the highest incidence of excerpts to those with the lowest incidence. Subsequently, with a horizontal analysis of the Matrix lines, also following the flow from the highest to the lowest incidence. This process was corroborated by the control of the percentages of columns and rows and based on the theoretical references adopted in the research. 
However, it should be clarified that for the presentation in this article, we have inserted the data for each course in a single $\mathrm{M}(\mathrm{K})$ Matrix, seeking to bring a compilation with evidence of the frequencies and absences observed for the three PCPs (Table 5) ${ }^{4}$.

\section{Presentation ANd ANALYSIS OF DATA}

Through the referrals exposed in the previous section, we present in Table 5 the General $\mathrm{M}(\mathrm{K})$ Matrix, which allows us to observe the numbering of selected excerpts from the analyzed and categorized PCPs.

Going through the General $\mathrm{M}(\mathrm{K})$ Matrix, the non-incidence of elements is evident in the second line - Personal dimension - and in the second column, related to teacher learning, that is, the K-T segment, detailed earlier in the sector descriptions $2 \alpha, 2 \beta$ e $2 \gamma$.

For each of the cells where excerpts were allocated, we will bring some examples, more specifically six for each PCP, out of a total of 288, 84 from PCP1, 107 from PCP2 and 97 from PCP3. In order to elucidate what was done, the full interpretation, as already informed, can be accessed in Levandovski (2019). It contains the three PCPs and the analytical organization of each Analysis Unit, together with the cell in which it was allocated.

Before starting the presentation of the excerpts, some information is in order: the parts in italics refer to the fragment of the excerpt that led us to insert it in that specific cell; when it does not exist, we considered the complete excerpt. In the first parenthesis at the end of the excerpt, we have what PCP it refers to - PCP1, PCP2 or PCP3; between square brackets we have the element of Structuring Axis II (Curriculum Organization) presented in Table 2 with shading, where the excerpt is described in the PCP; in the last parentheses we bring the numbering of the excerpt that was elaborated in ascending order during their organization, reading and interpretation ${ }^{5}$.

Right after the excerpt examples related to sector $1 \alpha$ we insert the General M(K) Matrix.

b) Recognize forms of racial, social, gender discrimination, etc., which are also based on alleged biological assumptions, taking a critical stand against them, supported by coherent epistemological assumptions and the reference bibliography; (PCP1) [Professional Profile] (excerpt number 7)

c) Acting in basic and applied research in different areas of Biological Sciences, committing to the dissemination of research results in appropriate vehicles to expand the dissemination and expansion of knowledge; (PCP2) [Professional Profile] (excerpt number 8)

\footnotetext{
${ }^{4}$ More details in Levandovski (2019).

5 The excerpts were translated from Portuguese. 
They must also be able to understand the historical process of knowledge construction in the field of biology, with regard to concepts, principles and theory, as well as an understanding of the meaning of biology for society and their responsibility as an educator in the various contexts of their professional performance, and showing themselves as a scientifically educated citizen, capable of making a critical reading of reality, realizing that living conditions do not only depend on biological causes, but also on social, political and economic issues. (PCP2) [Professional Profile] (excerpt Number 22)

4) Understand the historical process of production of knowledge in biological sciences regarding concepts/principles/theories; (PCP3) [Professional Profile] (excerpt Number 12)

\section{Examples related to sector $1 \gamma$ :}

The education of these professionals must be based on the conception of education as one of the elements of social transformation, aware of their responsibility as an educator in the various contexts of professional activity. (PCP1) [Objectives] (excerpt number 3)

b) Recognize forms of racial, social, gender discrimination, etc., which are also based on alleged biological assumptions, taking a critical stand against them, supported by coherent epistemological assumptions and the reference bibliography; (PCP1) [Professional Profile] (excerpt number 6)

In short, the undergraduate in Biology must be prepared to act as a producer and disseminator of knowledge; they must also be an educator and opinion maker, as well as a responsible citizen active in the preservation and conservation of the environment in which they live. (PCP2) [Professional Profile] (excerpt number 28)

2) Recognize forms of racial, social, gender discrimination, etc., which are also based on alleged biological assumptions, taking a critical stand against them, supported by coherent epistemological assumptions and the reference bibliography; (PCP3) [Professional Profile] (excerpt number 9)

10) Commit to constant professional development, assuming a posture of flexibility and availability for continuous changes, clear about union and corporate options inherent to professional practice. (PCP3) [Professional Profile] (excerpt number 18)

\section{Examples related to sector $3 \alpha$ :}

The undergraduate in Biological Sciences must have a basic, broad and solid, critical and creative training, with an adequate theoretical and practical foundation that includes in-depth knowledge of biological diversity, the organization from the macro to the microscopic level, its history and phylogenetic relationships, distribution patterns and relationships with the environment. (PCP1) [Professional profile] (excerpt number 20)

Execution of the Course Completion Work project in accordance with item 3.8. (PCP1) [Syllabuses] (excerpt number 80)

It is a time to diagnose how the practice takes place in the daily life of the school and its routine, taking a moment of analysis and reflection in order to understand the challenges that permeate the reality of the school and the education of the licentiate. (PCP2) [Supervised Internship] (excerpt number 46)

Education as a social and cultural practice and the school as one of the educational spaces. Historical studies of school organization and its educational projects from the 20th century onwards. The organization of education systems in the context of Basic Education in current Brazilian legislation: administrative and pedagogical aspects. Performance and teacher education. (PCP2) [Syllabuses] (excerpt number 80) 
Art. 72 The student who obtains an average equal to or greater than five (5.0), arithmetically drawn between the final average and the grade of the respective Final Exam, will be approved in the discipline or academic activity. (PCP3) [Assessment System] (excerpt number 23)

Article 30 Students working at home must undertake the Mandatory Supervised Internship in an alternative schedule, approved by the Course Collegiates, provided that the current legislation is respected. (PCP3) [Syllabuses s] (excerpt Number 96)

\section{Examples related to sector $3 \gamma$ :}

The training of these professionals must be based on the conception of education as one of the elements of social transformation, aware of their responsibility as an educator in the various contexts of professional activity. (PCP1) [Objectives] (excerpt number 2)

The training of these professionals must be based on the conception of education as one of the elements of social transformation, aware of their responsibility as an educator in the various contexts of professional activity. (PCP2) [Objectives] (excerpt number 2)

The Biological Sciences course - full time, in the licentiate and bachelor's degree modalities, aims to train professionals with knowledge and experience in Biological Sciences and the art of education, aiming at the development of education and science, the defense of the common good, the protecttion of the environment and the improvement of the quality of life in all its forms and manifestations. (PCP3) [Objectives] (excerpt number 2) 
Table 5 - General M(K) Matrix (PCP1, PCP2, PCP3)

\begin{tabular}{|c|c|c|c|c|}
\hline $\begin{array}{l}\text { Determinations } \\
\text { of knowledge }\end{array}$ & $\begin{array}{c}1 \\
\begin{array}{c}\text { About student learning } \\
\text { (K-S segment) }\end{array}\end{array}$ & $\begin{array}{c}2 \\
\text { About teacher } \\
\text { learning } \\
\text { (K-T segment) }\end{array}$ & $\begin{array}{c}3 \\
\text { About teaching } \\
\text { (T-S segment) }\end{array}$ & Totals \\
\hline $\begin{array}{c}\alpha \\
\text { Epistemic } \\
\text { (knowledge) }\end{array}$ & $\begin{array}{c}(7)(8)(10)(11)(13) \\
(21)(22)(23)(25)(26) \\
(27)(28) \\
(7)(8)(10)(11)(20) \\
(21)(22)(24)(25)(26) \\
(27) \\
(4)(6)(10)(12)\end{array}$ & & $\begin{array}{c}(1)(4)(20)(30)(31)(32)(33)(34)(35) \\
(36)(37)(38)(39)(40)(41)(42)(43)(44) \\
(45)(46)(47)(48)(49)(50)(51)(52)(53) \\
(54)(55)(56)(57)(58)(59)(60)(61)(62) \\
(63)(64)(65)(66)(67)(68)(69)(70)(71) \\
(72)(73)(74)(75)(76)(77)(78)(79)(80) \\
(81)(82)(83)(84) \\
(1)(4))(19)(29)(30)(31)(32)(33)(34) \\
(35)(36)(37)(38)(39)(40)(41)(42)(43) \\
(44)(45)(46)(47)(48)(49)(50)(51)(52) \\
(53)(54)(55)(56)(57)(58)(59)(60)(61) \\
(62))(63)(64)(65)(66)(67)(68)(69)(70) \\
(71)(72)(73)(74)(75)(76)(77)(78)(79) \\
(80)(81)(82)(83)(84)(85)(86)(87)(88) \\
(89)(90)(91)(92)(93)(94)(95)(96)(97) \\
(98)(99)(100)(101)(102)(103)(104) \\
\quad(105)(106)(107) \\
(1)(19)(20)(21)(22)(23)(24)(25)(26) \\
(27)(28)(29)(30)(31)(32)(33)(34)(35) \\
(36)(37)(38)(39)(40)(41)(42)(43)(44) \\
(45)(46)(47)(48)(49)(50)(51)(52)(53) \\
(54)(55)(56)(57)(58)(59)(60)(61)(62) \\
(63)(64)(65)(66)(67)(68)(69)(70)(71) \\
(72)(73)(74)(75)(76)(77)(78)(79)(80) \\
(81)(82)(83)(84)(85)(86)(87)(88)(89) \\
(90)(91)(92)(93)(94)(95)(96)(97)\end{array}$ & $85,5 \%$ \\
\hline $\begin{array}{c}\boldsymbol{\beta} \\
\text { Personal } \\
\text { (meaning) }\end{array}$ & & & & $0 \%$ \\
\hline $\begin{array}{c}\gamma \\
\text { Social (value) }\end{array}$ & $\begin{array}{c}(3)(5)(6)(9)(12)(14) \\
(15)(16)(17)(18)(19) \\
(24)(29)(85) \\
(3)(5)(6)(9)(12)(13) \\
(14)(15)(16)(17)(18) \\
(23)(28) \\
(3)(5)(7)(8)(9)(11) \\
(13)(14)(15)(16)(17) \\
(18)\end{array}$ & & (2) (2) (2) & $14,5 \%$ \\
\hline Totals & $22,8 \%$ & $0 \%$ & $77,2 \%$ & $100 \%$ \\
\hline
\end{tabular}

Source: Data obtained in the survey.

In this General $\mathrm{M}(\mathrm{K})$ Matrix, in which the PCP excerpts were jointly allocated, differentiated by colors (Table 5), a distributive pattern of textual fragments, objects of analysis in this research, was evident. 
What is observed, performing a vertical reading, are the determinations of knowledge about teaching, that is, in column $377.2 \%$ of the analyzed excerpts were inserted. With regard to student learning, the rate of excerpts was lower, $22.8 \%$ of the classified segments.

Starting with a horizontal reading of the Matrix, the emphasis is on the epistemic dimension of knowledge, $85.5 \%$ of the excerpts allocated in the first line and only $14.5 \%$ of them in line 3 related to the social dimension.

Considering the analysis of documents was undertaken in the research and aimed at an impersonal reading, the gap in excerpts in line 2, of the relations of knowledge in the personal dimension, is justified. Such personal aspect presents itself with justifiable indices in the case of the Teacher (ARRUDA; LIMA; PASSOS, 2011) and Student (ARRUDA; BENICIO; PASSOS, 2017) matrices, aimed at the analysis of positions extracted through interviews. In this case, differently, the analysis of documents prepared for impersonal application was addressed, that is, for all teachers who train the courses involved and their students, with requirements and determinations aimed at the interpersonal dimension due to the very nature of the document that has as its conceptual object, to conceptualize, organize, and regulate the course.

An important gap in the investigated PCP was evidenced by the analysis of the three Matrices. It is about the absence of excerpts in column 2 of the $M(K)$, dedicated to the determinations of knowledge in relation to teacher learning, which concerns teacher trainers. This absence surprised us, considering the importance of providing guidance for professionals who implement the PCP on a daily basis. The absence of arguments aimed at the teachers of the courses revealed a dimension not addressed in the PCP and which leads us to the three vertices - Teacher, Student, Knowledge - of the didactic-pedagogical triangle, which is the base structure for the elaboration of the Knowledge Matrix and of other Matrices that can be accessed in Arruda and Passos (2017).

The PCPs present what students need to learn as future professionals. They deal with which contents are important in the disciplines and how the other components need to be fulfilled. But they do not make any mention or provide considerations to the trainer teachers about how to conduct their classes (methodological aspects), how to think about content perspectives (epistemic aspects, as in the case of the evolutionary perspective of biological sciences), in short, how to develop the conditions of teacher action (TARDIF, 2000, 2002; GAUTHIER et al., 2013; ARRUDA; LIMA; PASSOS, 2011). 


\section{FINAL CONSIDERATIONS}

Considering that the research question was a guide for conducting the research, whose results we present in this article, it was deemed necessary to return to it in order to outline the conclusions we reached. How do the Pedagogical Course Projects (PCP) in Biological Sciences guide the pre-service teacher education, from the perspective of the Knowledge Matrix $-\mathrm{M}(\mathrm{K})$ ?

The investigative path and, consequently, the methodological approach developed in the research had the general objective, therefore, to analyze the pre-service education of Biological Sciences teachers, from the Pedagogical Course Projects, based on the relationships present in the Knowledge Matrix - M(K).

During the development of the investigation, some elements of the Knowledge Matrix, when applied to the analysis of PCP, proved to be extremely relevant, such as the lines: relationship with epistemic knowledge and with social knowledge, since its application enabled objective results and that could be critically analyzed based on the literature on which the research was based.

As we have shown, the PCPs did not dedicate space to deal with the teacher trainer, to advise them on teaching, on assessment, on the subjects or any other elements that were interposed in their practice as a teacher trainer of teachers. Also, in the analyzed documents, no mentions were found that higher education institutions required this in the Pedagogical Course Projects.

Regarding the absence of records related to relationships with knowledge in the personal dimension (line 2 of the Knowledge Matrix), this was a justified finding, in the data analysis, due to the nature of the documents studied (PCP), which were dedicated to the descriptive record of the conceptions, organization and regulations of the course itself, with no formal space for personal records.

Thus, the developed research worked with the understanding that it would be pertinent to think about the structuring of Pedagogical Course Projects (or adapt the existing ones) in terms of the components of the $\mathrm{M}(\mathrm{K})$, in order to contemplate issues specific to teacher learning, the learning intended to the teacher trainer, but without subtracting from this undertaking the other determinations of knowledge (student learning and teaching) of the epistemic, personal and social relationships indicated in the Matrix.

In terms of personal aspects, for example, in the case of line 2 of the $M(K)$, it could be taken as a suggestion the existence of specific sections in the PCP that give voice to students 
and teacher trainers to express opinions about what was expected when making the proposal of such Project, or at least register reports and possibilities of future actions to improve it.

These perceptions were only possible through the use of $\mathrm{M}(\mathrm{K})$ and its adaptations, enabling a systemic look and the relationship between the epistemic, personal and social dimensions of the courses in relation to student learning, teacher learning and teaching.

The $\mathrm{M}(\mathrm{K})$, therefore, offered theoretical and methodological conditions so that it was possible to visualize similarities and differences between the courses studied, but, above all, the gaps that need to be overcome for a coherent and cohesive training in Biological Sciences with the current socio-historical context..

It is believed to be pertinent to give feedback to courses, especially to those investigated, on how their PCPs could be thought of in terms of the Knowledge Matrix. Adding to this, the expansion of this discussion so that such guidelines can be generalized by educational institutions, with the necessary adaptations.

It is worth emphasizing how informative it was to use the $\mathrm{M}(\mathrm{K})$ as an analysis tool. Through it, it was possible to perceive in the PCP its strengths and gaps, its possibilities and its limits, as well as glimpse alternatives that signaled an improvement in the quality of the instrument, which will certainly reflect on the quality of the education of the future teacher.

\section{REFERENCES}

ARAÚJO, Roberta Negrão de. A formação da identidade docente no contexto do PIBID: um estudo à luz das relações com o saber. 2017. 165f. Tese (Doutorado em Ensino de Ciências e Educação Matemática). Universidade Estadual de Londrina, Londrina, 2017.

ARROYO, Miguel González. Educandos e Educadores: seus direitos e o currículo. In: BRASIL. Ministério da Educação e da Cultura. Indagações sobre o currículo. Brasília, 2008. p. 17-51.

ARRUDA, Sergio de Mello; BENICIO, Marily Aparecida; PASSOS, Marinez Meneghello. Um instrumento para a análise das percepções/ações de estudantes em sala de aula. Revista Brasileira de Ensino e Tecnologia, Ponta Grossa, v. 10, p. 1-12, 2017.

ARRUDA, Sergio de Mello; LIMA, João Paulo Camargo; PASSOS, Marinez Meneghello. Um novo instrumento para a análise da ação do professor em sala de aula. Revista Brasileira de Pesquisa em Educação em Ciências, [s. l.], v. 11, p. 139-160, 2011.

ARRUDA, Sergio de Mello; PASSOS, Marinez Meneghello. A relação com o saber na sala de aula. In: EDUCOM - Colóquio Internacional "Educação e Contemporaneidade", 9., 2015, Aracaju. Anais [...]. Aracaju, 2015. Disponível em:

http://educonse.com.br/ixcoloquio/arruda passos2.pdf. Acesso em: 02 out. 2021. 
ARRUDA, Sergio de Mello; PASSOS, Marinez Meneghello. Instrumentos para a análise da relação com o saber em sala de aula. Revista de Produtos Educacionais e Pesquisas em Ensino - REPPE, Cornélio Procópio, v. 1, n. 2, p. 95-115, 2017.

ARRUDA, Sergio de Mello; PASSOS, Marinez Meneghello; BROIETTI, Fabiele Cristiane Dias. The research program on teacher action, student action and their connections (PROACTION): fundamentals and methodological approaches. Revista de Produtos Educacionais e Pesquisas em Ensino - REPPE, Cornélio Procópio, v. 5, n. 1, p. 215-246, 2021.

BARDIN, Laurence. Análise de conteúdo. São Paulo: Edições 70, 2011.

BOGDAN, Robert; BIKLEN, Sari Knopp. Investigação Qualitativa em Educação: uma introdução à teoria e aos métodos. Porto: Porto Editora, 1994.

BRASIL. Conselho Nacional de Educação. Parecer CNE/CES n⿳ 1.301, de 06 de novembro de 2001. Diretrizes Curriculares Nacionais para os Cursos de Ciências Biológicas. 2001. Disponível em: http://portal.mec.gov.br/cne/arquivos/pdf/CES1301.pdf. Acesso em: 23 mar. 2018.

BRASIL. Conselho Nacional de Educação. Resolução CNE/CES n 2 , de 19 de fevereiro de 2002-A. Institui a duração e a carga horária dos cursos de licenciatura, de graduação plena, de formação de professores da Educação Básica em nível superior. Disponível em: http://portal.mec.gov.br/cne/arquivos/pdf/CP022002.pdf. Acesso em 02 mar. 2018.

BRASIL. Conselho Nacional de Educação. Resolução CNE/CES n 7, de 11 de março de 2002-B. Diretrizes Curriculares Nacionais para os Cursos de Ciências Biológicas. Disponível em: http://portal.mec.gov.br/cne/arquivos/pdf/CES07-2002.pdf. Acesso em 23 mar. 2018.

BRASIL. Lei no 9.394/96. Fixa as Diretrizes e Bases da Educação Nacional. Disponível em: http://www.planalto.gov.br/ccivil 03/leis/L9394.htm. Acesso em: 07 mar. 2019.

BRASIL. Lei $\mathbf{n}^{\mathbf{0}}$ 6.684/79. Conselho Federal de Biologia. Regulamenta as profissões de Biólogo. 1979. Disponível em: http://www.cfbio.gov.br/artigos/LEI-N\%C2\%BA-6684-DE-3DE-SETEMBRO-DE-1979. Acesso em: 09 ago. 2018.

CHARLOT, B. Da relação com o saber: elementos para uma teoria. Porto Alegre: Artmed, 2000.

CORRÊA, Hugo Emmanuel da Rosa; ARRUDA, Sergio de Mello; PASSOS, Marinez Meneghello Passos. A construção de uma estrutura curricular flexível: uma análise a partir da Matriz do Saber. Ciência e Natura, [s. l.], v. 42, p. 1-24, 2020.

DARLING-HAMMOND, Linda. A importância da formação docente. Cadernos Cenpec/Nova série, [s. l.], v. 4, n. 2, 2015.

GAUTHIER, Clermont; MARTINEAU, Stéphane; DESBIENS, Jean-François; MALO, Annie; SIMARD, Denis. Por uma teoria da pedagogia: pesquisas contemporâneas sobre o saber docente. 3. ed. Ijuí: Editora Unijuí, 2013. 
LATOUR, Bruno. A Esperança de Pandora. Bauru: Edusc, 2001.

LEVANDOVSKI, Ana Rita. A Formação Inicial de Professores de Ciências Biológicas: uma análise do Projeto Pedagógico de Curso a partir da Matriz do Saber. Defesa. 2019. 212f. Tese (Doutorado em Ensino de Ciências e Educação Matemática) - Universidade Estadual de Londrina, Londrina, 2019.

MARTINEAU, Stéphane; GAUTHIER, Clermont. Vers une meilleure comprehension des savoirs disciplinaires et curriculaires des enseignants ou Ie paradigme retrouve. Brock Education Journal, [s. l.], v. 9, n. 1, 1999.

MORAES, Roque; GALIAZZI, Maria do Carmo. Análise Textual Discursiva. Ijuí: Unijuí, 2011.

NÓVOA, António Manuel Seixas Sampaio da. Professores imagens do futuro presente. Lisboa: Educa, 2009.

PIMENTA, Selma Garrido. Formação de professores: saberes da docência e identidade do professor. Nuances, [s. l.], v. 3, p. 5-13, 1997.

RISSI, Debora Regina da Silva. Uma proposta de organização do ensino de Química para o Ensino Fundamental. 2020. 71f. Dissertação (Mestrado Profissional em Ensino) Universidade Estadual do Norte do Paraná, Cornélio Procópio, 2020.

TARDIF, Maurice. Saberes Docentes e Formação Profissional. 17. ed. Petrópolis: Vozes, 2002.

TARDIF, Maurice. Saberes profissionais dos professores e conhecimentos universitários. Revista Brasileira de Educação, [s. l.], v. 13, n. 5, p. 5-24, 2000.

SACRISTÀN, José Gimeno. O que significa o currículo? In: SACRISTÀN, José Gimeno (Org.). Saberes e incertezas sobre o currículo. Porto Alegre: Penso, 2013.

SILVA, Tomaz Tadeu da. Documentos de Identidade: uma introdução às teorias curriculares. Belo Horizonte: Autêntica, 2017.

SHULMAN, Lee S. Conocimiento y enseñanza: fundamentos de la nueva reforma. Profesorado. Revista de Currículum y Formación del Profesorado, Granada, ano 9, n. 2, p. $1-30,2005$.

SHULMAN, Lee S. Those Who Understand: Knowledge Growth in Teaching. Educational Researcher, Thousand Oaks, California, v. 15, n. 4, p. 4-14, 1986.

VEIGA, Ilma Passos Alencastro. Educação Básica e Educação Superior: projeto político pedagógico. Campinas, Papirus, 2004.

\section{ACKNOWLEDGMENTS}

Our thanks to $\mathrm{CNPq}$ for the financial support. 